УДК 378.147 .88

DOI https://doi.org/10.32838/2663-6069/2019.2-1/15

Duzhyk N.S.

National University of Food Technologies

\title{
FILM AS A MEANS OF SOCIAL AND EMOTIONAL LEARNING IN HIGHER EDUCATION
}

Integration of social and emotional learning into the education process has been one of the most popular international trends for over 20 years. This article reviews the general approaches to implementing the social and emotional learning model in higher education. The model's merits are also discussed in relation to foreign language training, especially its effectiveness in reaching academic and non-academic objectives. Using film episodes is an effective tool of expanding students'vocabulary and practicing the English language with a greater confidence and precision. This enables students to develop emotional sensitivity and conflict resolution skills, to display a socially cultivated behavior and learn advanced communication practices. The paper provides a film-based framework to encourage the development of a wide range of socioemotional competencies in response to emerging challenges.

Key words: English language instruction, film-based learning, collaboration, conflict resolution, emotional intelligence.

Problem statement. For over 20 years educational institutions in different countries (the USA, Canada, the UK, Australia etc) have been implementing Social Emotional Learning (SEL) programs at different education levels. The need in emotional intervention for enhancing academic performance was linked to cognitive activities and was recognized as a general approach to learning a long time ago $[3 ; 10]$. It is proved that students learn and remember best when their emotions are engaged [4]. This approach is especially effective when incorporates films into teaching. University curricular provide extensive ground for using it.

Literature review. An extensive body of literature reveals that the SEL approach is highly relevant in the university settings, especially during the first year of studies [2]. Recent high-school graduates find themselves in a differently structured, more demanding environment which requires fast adaptation to new roles, challengingly paced courses, and classmates/roommates coming from different cultural and socioeconomic backgrounds. Increased pressures can cause stress, adjustment difficulties, and even mental health problems. Sometimes the inability to overcome barriers to academic success makes students vulnerable to risky behaviors, such as alcohol and drug use, non-monogamous sex, violence and bulling. Students' disengagement from rigorous studies, truancy, and conduct problems often result in academic failures and dropping out of the university. To ease the transition period for freshmen, universities choose a SEL model which is the most suitable to their particular needs.

The direct way of supporting students' development is introducing SEL in the curriculum. This approach was implemented by Widener University, PA, USA. Each fall semester 23 freshman seminars (FRS101) are offered. The seminar is a one-credit elective course for students in all academic majors. A range of topics is defined by the seminar's primary objective to equip students with the skills and resources necessary for successful academic performance and general well-being. However, emotional intelligence is viewed as a basic competence used in the service of successful social functioning [8].

Along with explicit instructions on using the SEL competencies, educators integrate the SEL content into core academic subject areas, including English/ Language Arts [6]. Experience-based approaches address social and emotional dimensions of learning by fostering interactivity, connectedness, and collaboration. In planning academic activities, a big importance is attached to students' demographic, backgrounds and lifestyle.

The use of films in the classroom is in line with the youth regular exposure to visual culture, the desire to have fun, to discover new enjoyable entertaining pieces and share them with peers. Films' ability to deliver pleasure and provide learning content, to create a relaxing, informal atmosphere, and introduce 
students to complex issues are main reasons for faculty members to incorporate films in the curriculum. Films are especially suitable for delivering SEL in conjunction with interactive methods (discussion, role-play, games). Depending on the lesson objectives, the teacher can choose to watch a whole film, particular scenes, or just an episode.

The aim of the paper is to demonstrate the powerful potential of films for serving the SEL objectives. We choose a café scene from the Bollywood film English-Vinglish (https://www.youtube.com/ watch? $v=$ Mr6E_9TQtQs). The film is about the Indian woman Shashi who came to New York to help her sister with wedding preparations. Her limited knowledge of English is an obstacle to effective communication with foreigners. The café scene plays an important role for the whole plot because after visiting the café, Shashi decided to enroll in an English language program with New York Language Center.

This video can be used as a model for practicing real-life activities, such as ordering food in a café, for evaluating professional performance and deciding on the question "What makes a true professional?", for discussing the importance of learning foreign languages, or for the deep exploration of the topic "Feeling and Emotions".

Discussion. Our film-based toolkit "From Food to Mood" encompasses a variety of instructional materials, such as a transcript, a vocabulary list, and professional guidelines, to support students' activities and ensure their successful completion.

The manifold purpose of the lesson includes: reviewing and learning new vocabulary for food and emotions, practicing spoken English in relation to real life situations, eliciting an emotional response to the video, developing cultural sensitivity and conflict resolution skills, encouraging critical thinking and creativity in response to emerging problems, and comparing foreign and native cultures for social behavior standards and common communication practices.

Before watching: Warming up activities for small groups (3-4 students). Answer these questions.

1. How often do you eat out?

2. Do you go out for a meal alone or with other people?

3. What kind of places do you prefer for breakfast, lunch, and dinner? Explain your choice.

4. Do you normally tip the waiter / waitress?

5. When can ordering food be stressful?

While watching the café episode, students are asked to identify a number of participants important to the scene. (In practice, students' groups come up with a different number of significant participants. Often it generates the discussion among students about correctness of their choices, especially creative ones, for example the passing bus with the advertisement of New York Language Center).

After watching: Answer the questions about the episode you have watched (discussion).

1. How did the barista address Shashi when saw her in the line?

2. How do you characterize the barista's behavior? Is this the way to serve the customers?

3. Can you justify the café staff behavior?

4. Were there any particular words or phrases in the dialog triggering changes in the characters' moods?

5. Can it happen in real life/in your country? Would people in your country react differently to the events in the café?

After watching the scene for the second time, recite the café dialog and record it. (The full transcript of a café scene is included in Appendix 1).

Also students can lip-synch the scene. The activity is evaluated by the following questions:

1. Which pair of students performed best?

2. Whose facial expressions and gestures were the most convincing and expressive?

3. Did you notice any cultural differences in body language and facial expressions in the film scene?

Defining emotions. Split into three groups A, $\mathrm{B}$, and $\mathrm{C}$ and write down the words describing people's character traits and emotions in the cafe: Group A describes Shashi, Group B observes Barista, and Group $\mathrm{C}$ focuses on the people in the line. Discuss the impact of the major participants on the café scene. Defend your point of view if your group's partners disagree. Use Table 1 (Appendix 2) for performing this task $[1 ; 5]$.

Matching the film screenshots, highlighting the characters' emotional state to corresponding words, is an effective way to learn a new vocabulary as well as to practice familiar words and phrases. In addition, it supports other educational tasks, such as finding the ways to deal with negative emotions which can be detrimental to an individual's personality. Negative emotions should not be ignored and can be used as a psychological resource for development [9]. In this regard, educators' role in creating a safe, fun environment for effective learning and meaningful interaction is crucial.

Performance evaluation. Read the Guidelines for food service personnel. Evaluate the café staff customer service against the established standards. Think how to organize a business capable of dealing with representatives of other cultures who have difficulty ordering food. 
Make every effort to create an inviting atmosphere. Treat each customer warmly and with respect.

Provide your guest with great service and food of their best choice.

Describe specials in an appealing way instead of reciting them in monotone.

Listen to your customers and hear what they are saying.

Interact with customers to their full satisfaction.

Demonstrate resourcefulness, good manners, and patience when dealing with difficult clients.

Don't get chatty with customers.

Remember the customer is always right.

Always say "Thank you".

Homework should be a challenging enough task providing the opportunity for individual or group work. It is beneficial to give students a variety of choices or consult them on choosing their own assignment. For example, students can choose among the following tasks:

Present the dialogue between a barista and a café guest, representative of other culture, in which high standards of customer service are demonstrated.

Write an email to the coffee shop manager about the customer service observed and include your suggestions on improving it.

Write a diary entry as Shashi/a cafe employee/a café visitor. Include your reflections on the café scene.

English-Vinglish is an engaging and thoughtprovoking film suitable for university students possessing different learning styles. Its motivational message is pointed at all human beings - winners and losers - and is especially important for students struggling with their studies. For such learners, the café scene is understandable enough and serves as a good means for learning new vocabulary and engaging in interactive activities. Advanced students have ample opportunities to help their classmates practice English speaking, develop communication skills, and find creative solutions to presented problems in an informal and bonding environment.

The emotional component of the film-based framework stimulates students' active participation, their interest in relevant discussion points, helps them overcome their language use incompetency as well as boosts their curiosity. The lesson impact may prompt students to borrow the film from a library or buy it online. They might search for the film reviews on the Internet, read the biographies of actors, and learn additional information about the cultures featured in the film.

The planning, implementation and systematic analysis of film-based activities have given us the grounds for highlighting important lessons about social and emotional learning. Although our conclusions are not rigorously tested, they present activity-based support for implementing a SEL model into core academic subject areas and demonstrate how to facilitate in-class work.

Incorporation of the café scene lasting less than 5 minutes into a relevant thematic lesson can produce a number of beneficial results some of which worth reiterating.

As a less traditional, more informal and entertaining method, it has a greater appeal to students and is easily applied in small groups.

This flexible approach enables the use of diverse methods of instruction (discussion, role-play, dubbing, content evaluation, multimedia presentation etc).

It allows to individualize learning and differentiate individual and collective contributions to problemsolving and conflict-resolution activities.

It is an efficient vehicle for team-building, creating a comfortable and supportive learning environment.

It clearly demonstrates the complexity of interpersonal communication and multiple ways to resolve conflicts.

It fosters self-awareness, social awareness, empathy, and sensitivity to other people's feelings.

It spreads the message about globalization, cultural differences, the importance of learning foreign languages as a means of international communication, and prepares students for future encounters with foreigners.

It can enhance students' self-esteem, motivate them to overcome negative life circumstances with determination and perseverance. In some groups, students with an insufficient language competence but strong problem-solving skills impressed their co-eds with creative solutions to the food ordering problem (for example, to let Shashi serve herself / to make her own sandwich).

It is important to empower students in a way that they feel comfortable to make their own suggestions in regard to the education process in general and their assignments particularly. After having received their home assignment at the end of the lesson, some students voiced the opinion that enough attention had been given to the film episode in class and they would rather do something different. Alternatively, they chose to give a presentation on a related topic, such as Life of Women in Contemporary India or Afro-American Community in New York.

Conclusion. The SEL model is flexible enough to account for the changing world and respond to global 
challenges. Its pointedness at multiple areas of human development has brought it international recognition. Its positive outcomes are widely recognized and include improvements in students' academic performance, changes in values and attitudes toward self and others, acquiring a range of skills necessary for academic success, social and professional life.

Films are a reliable means of enhancing the emotional impact on language learning. Along with serving academic goals, they stimulate cognitive activity, propagate moral values, help learners relax and explore complex problem in a visual, artistic way. The plethora of resources on SEL makes it possible to turn it into a sustainable program implemented across all disciplines and levels of education. Moreover, its interactive dimensions help identify different learning styles and facilitate them. This process should be guided by students' enthusiasm aimed at making the world a better place and at becoming a good student, a good friend, and a good citizen.

\section{References:}

1. Cambridge Dictionary. URL: https://dictionary.cambridge.org/.

2. Conley C. SEL in Higher Education. Handbook of Social and Emotional Learning. Research and Practice, Faculty Publications. 2015. P. 197-212. URL: https://ecommons.luc.edu/cgi/viewcontent.cgi?referer=https:// search.yahoo.com $/ \&$ httpsredir $=1 \&$ article $=1035 \&$ context=psychology_facpubs.

3. Dymnicki A. Improving College and Career Readiness by Incorporation Social and Emotional Learning. 2013. March. P. 23. URL: https://ccrscenter.org/sites/default/files/Improving $\% 20$ College $\% 20$ and $\% 20$ Career $\% 20$ Readiness\%20by\%20Incorporating\%20Social\%20and\%20Emotional\%20Learning_0.pdf.

4. Hromek R. \& Roffey S. Promoting social and emotional learning with games: It's fun and we learn things. Simulation \& Gaming. 2009. Vol. 40. № 5. P. 626-644.

5. MacMillan Dictionary. URL: https://www.macmillandictionary.com.

6. Ragozzino K. et al. Promoting Academic Achievement through Social and Emotional Learning. Educational Horizons. Summer 2003. P. 169-171. URL: http://eds-courses.ucsd.edu/eds379B/wi10/205A\%20W10/ Ragozzino.pdf.

7. Restaurant Service. WorldSkills. URL: https://www.worldskills.org/skills/id/246/.

8. Wang N. Impact of a College Freshmen Social and Emotional Learning Curriculum on Student Learning Outcomes: An Exploratory Study. Journal of University Teaching \& Learning Practice. 2012. Vol. 9. № 2. URL: https://files.eric.ed.gov/fulltext/EJ984909.pdf.

9. Yasuhiro I. Emotions in SLA: New Insights from Collaborative Learning for an EFL Classroom. The Modern Language Journal. 2010. Vol. 94. № 2. P. 278-292.

10. Zeelenberg R. et al. The impact of emotion on perception. Psychological Science. 2006. Vol. 17. № 2. P. 287-291.

\section{ХУДОЖНІЙ ФІЛЬМ ЯК ЗАСІБ СОЦІАЛЬНО-ЕМОЦІЙНОГО НАВЧАННЯ У ВИЩІЙ ШКОЛІ}

Соціально-емоційне навчання $\epsilon$ однією з найбільш популярних освітніх технологій, яка використовується в різних країнах понад 20 років. У статті вказані основні підходи до впровадження сочіально-емоційного навчання у вищій школі. Переваги ичієї моделі також розглянуто для вивчення іноземної мови, особливо ї̈ ефективність у досягненні навчальних і позааудиторних иілей. Використання епізодів із художніх фільмів дає змогу збільшувати словниковий запас студентів, а також послуговуватися англійською мовою більш упевнено й точно. Цей підхід уможливлює розвиток емоційного інтелекту, уміння долати конфліктні ситуації, засвоювати норми сочіально прийнятної поведінки, а також новітні комунікативні стандарти. Показано, як використання художніх фільмів сприяс розвитку різних сочіально-емочійних компетенцій у відповідь на виклики часу.

Ключові слова: навчання аналійської мови, художній фільм, співпрачя, подолання конфлікту, емоиійний інтелект.

\section{ХУДОЖЕСТВЕННЫЙ ФИЛЬМ КАК СРЕДСТВО СОЦИАЛЬНО-ЭМОЦИОНАЛЬНОГО ОБУЧЕНИЯ В ВЫСШЕЙ ШКОЛЕ}

Соииально-эмочиональное обучение является лидирующей технологией в сфере образования, которая используется в разных странах более 20 лет. В статье указаны основные подходы к внедрению сочиально-эмочионального обучения в высшей школе. Преимущества этой модели также рассмотрены для изучения иностранного языка, особенно ее эффективность в достижении учебных и внеаудиторных иелей. Использование эпизодов из художественных фильмов позволяет увеличить словарный 
запас студентов, а также овладевать английскии языком более уверенно и точно. Этот подход стимулирует развитие эмоционального интеллекта, умение преодолевать конфликтные ситуации, усваивать нормы социально приемлемого поведения, а также новейшие коммуникативные стандарты. Показано, как использование художественных фильмов может способствовать развитию различных соииально-эмоциональных компетенций в ответ на вызовы времени.

Ключевые слова: обучение английского языка, художественный фильм, сотрудничество, преодоление конфликта, эмочиональный интеллект.

APPENDIX 1

Transcript. CAFÉ SCENE. ENGLISH VINGLISH (2012). Comedy, Drama, Family. 2 h 14 min. Director and Writer: Gauri Shinde.

Barista: Next! How you doing today ma'am?

Shashi: I want...

Barista: I asked how you were doing today

Shashi: Doing... I'm doing... I'm doing...

Barista: You can't take all that time. I got a long line here.

Shashi: Sorry... what to eat?

Barista: Are you kidding me right now... Please, hurry up lady

Shashi: Vegetarian...

Barista: Vegetarian is fine... what do you want to eat?

Shashi: Only vegetarian...

Barista: A bagel... a wrap... a sandwich?

Shashi: Sandwich

Barista: OK. And what kind of filling do you want inside? Do you want cheese... tomatoes... lettuce..?

Shashi: Ha...?

Barista: Lady...Do you see. You're holding up my line. This is not rocket science. Cheese?

Shashi: Ha... Cheese

Barista: Yes to cheese! Anything to drink?

Shashi: Water...

Barista: Still or sparkling?

Shashi: Only water

Barista: Still or sparkling?

Shashi: Coffee..?

Barista: Americano? Cappuccino? Latte?

Shashi: A man in the line: Lady... I ain't got all day...

Barista: Americano? Cappuccino? Latte?

Shashi: 'Nescoffee'

Barista: What?

Shashi: 'Nescoffee'

Barista: Yes we have nice coffee. We have the best coffee in Manhattan. You know what? I'll give you an Americano. Small or medium?

Shashi: Small.

Barista: Is that it? 10 dollars and 20 cents.

Shashi: 10 dollars... Sorry.

Barista: Hello... the least you could do is say thank you!

Shashi: Sorry... thank you...

Men's voices: Stupid! Idiot! What are you doing?

Shashi: Sorry...

Barista: I am not cleaning that up!

Men's voices: Don't bother... What a stupid woman! Can I get another one?

The man who was in the line behind: Madam. Your coffee from the coffee shop. Cafe not good. Woman... not nice! 
Emotions and Character Traits

\begin{tabular}{|c|c|c|c|}
\hline № & Word & Pronunciation & Definition and Sentence Examples \\
\hline 1 & Annoyed & /a'nord/ & $\begin{array}{l}\text { feeling slightly angry or impatient. We were all annoyed with him } \\
\text { for forgetting. }\end{array}$ \\
\hline 2 & Chatty & /'tfæti/ & tending to talk a lot: fond of chatting. I'm feeling chatty today. \\
\hline 3 & Confused & /kən'fju:zd/ & $\begin{array}{l}\text { unable to understand something or think clearly about it. She was } \\
\text { starting to feel a bit confused. }\end{array}$ \\
\hline 4 & Embarrassed & /Im'bærəst/ & $\begin{array}{l}\text { ashamed of something and worried about what other people } \\
\text { will think of you. I've never felt so embarrassed in my entire life. }\end{array}$ \\
\hline 5 & Humble & /'h $\Lambda \mathrm{mbl} /$ & $\begin{array}{l}\text { not proud and not thinking that you are better than other people. He } \\
\text { was a genuinely humble man. }\end{array}$ \\
\hline 6 & Humiliated & /hju: 'mılieitıd/ & feeling ashamed or stupid. I've never felt so humiliated in my life. \\
\hline 7 & Impatient & /Im'perfnt/ & $\begin{array}{l}\text { annoyed because something is not happening as quickly as } \\
\text { you want or in the way you want. He gets impatient with people who } \\
\text { don't agree with him. }\end{array}$ \\
\hline 8 & Indifferent & /In'difrənt/ & $\begin{array}{l}\text { lacking interest in something, or lacking sympathy with someone. } \\
\text { It's easy to be indifferent to money when you've never been poor. }\end{array}$ \\
\hline 9 & Insensitive & /In'sensətiv/ & $\begin{array}{l}\text { not noticing or caring about other people's feelings or needs, and } \\
\text { not worrying that things that you say or do may upset them. He } \\
\text { is totally insensitive to my feelings. }\end{array}$ \\
\hline 10 & Intimidating & /In'tımideitıy/ & $\begin{array}{l}\text { making you feel frighten, nervous or less confident. We certainly w } \\
\text { eren't friends with our teachers - we found them very intimidating. }\end{array}$ \\
\hline 11 & Irritated & /'iriteitid/ & $\begin{array}{l}\text { annoyed or impatient about something. I've never seen him looking } \\
\text { so irritated. }\end{array}$ \\
\hline 12 & Lovely & /'1 $\Lambda$ vli/ & $\begin{array}{l}\text { very attractive; kind, pleasant, and easy to like. He's a lovely little } \\
\text { boy. }\end{array}$ \\
\hline 13 & Miserable & /'mızrəbl/ & $\begin{array}{l}\text { extremely unhappy or uncomfortable. When I'm feeling miserable } \\
\text { I go shopping and spoil myself. }\end{array}$ \\
\hline 14 & Reserved & /ri'zə:vd/ & $\begin{array}{l}\text { slow to reveal emotion or opinions. The English have a reputation } \\
\text { for being reserved. }\end{array}$ \\
\hline 15 & Snappy & /'snæpi/; & feeling or showing irritation; She was awfully snappy with me. \\
\hline 16 & Upset & / $\Lambda p^{\prime}$ set/ & $\begin{array}{l}\text { very sad, worried, or angry about something. She feels upset that } \\
\text { we didn't tell her the truth. }\end{array}$ \\
\hline
\end{tabular}

